UDC 336

\title{
Assessing methodology of banks' ratings and their competitive positions: overview of main rating agencies
}

\author{
Elena M. Grigorieva, Darko Vukovic \\ Peoples' Friendship University of Russia (RUDN University) \\ 6 Miklukho-Maklaya St., Moscow, 117198, Russian Federation
}

\begin{abstract}
This paper analyzes methodologies of credit rating assessment of major rating agencies, with the focus on Fitch Ratings (Fitch). The methodology data were collected from Fitch Ratings. Also, the article review international literacy for factors and indicators adequacy in rating assessments. The purpose of this research is to overview literacy for the primary methodologies of banks' credit rating assessment. It was explained that ratios from financial indicators are most important for credit rating assessment. In some cases, in sovereign countries, support and macroeconomic factors are significant. We concluded that this area is still not enough researched and that in the future, the number of studies will appear with different methodological proposals and improvements.
\end{abstract}

Keywords: credit rating, banks, credit rating agencies, methodology, assessment, Fitch

\section{Introduction}

Banks (commercial banks) are depository companies (institutions) that provide lending services, deposits, and savings operations, as also many other services as their part of off-balance-shit activities. They build their competitive position on the broadest possible range of services, which are competitively priced, with the best possible credit (or default) rating. With a higher bank rating, investors are more likely to deposit their funds or to invest in their securities provided by a particular bank. On the other hand, the bank has the advantage of a lower cost of capital accumulation (lower interest rates on demand deposits, negotiable order of withdrawal accounts, passbook savings accounts and money market deposit accounts) and a better negotiating position with the instruments like retail time deposits and wholesale CDs (Certificate of Deposits). Strategically, a critical bank aims to achieve a better rating (credit rating) in order to have these benefits (cheaper capital and greater confidence of investors). Therefore, the matter is how is essential a bank's rating (commercial banks, policy banks, and bank holdings) for its strategic competitiveness in the money, capital, and securities markets.

Many external and internal factors influence national banking systems. This influence determines the share of foreign capital, the level of state participation,

(C) Grigorieva E.M., Vukovic D., 2020

(c) (i) This work is licensed under a Creative Commons Attribution 4.0 International License https://creativecommons.org/licenses/by/4.0/ 
the degree of concentration of assets, as well as the regulatory and competitive environment.

The high degree of vulnerability of the banking system from external shocks, market risks, and cyclical economic development, influence on developing different tools that allow to assess and predict their stability and competitiveness. Such a tool is rating assessment, in particular, the rating methodology used by specialized international rating agencies.

The implementation of the Basel agreement (2004) and its further improvement was as a stimulating factor for the development and application of rating models. Basel II recommended the introduction of specialized internal rating systems, based on which the rating of borrowers is evaluated, and the level of formed reserves are selected in accordance with their level. The Basel III approach recommends using borrowers' credit ratings when assessing bank capital adequacy. It is recommended to use the method of advanced internal ratings - IRBapproach (Internal Ratings-Based Approach) - or to use the ratings of accredited rating agencies.

However, a bank's credit rating depends on several indicators that are rated by the agencies. In assessing banks' ratings, investors and stakeholders most commonly use the methodology, the criteria, and reports of major credit rating agencies such as Fitch Ratings (Fitch), Moody's Investor Services (Moody's) and Standard and Poor's (S \& P). These institutions have similar methodologies for the rating of banks, taking into account the bank's intrinsic creditworthiness and external factors that influence the bank's default rating. As first, they estimate the bank's internal or solely financial strength, viability rating (like operating environment, financial data, managerial and operating effectiveness, risk aversion), the business environment in a specific region (macroeconomic factors), default risk and debt indicators. They used both in assessing banks' ratings, quantitative assessments of credit risk (financial indicators), and the expert assessments (qualitative indicators) (Chodnicka-Jaworska, 2019; Grunert et al., 2005). According to the same author (2019), such indicators are risk appetite, the economic and operational environment, different financial ratios (profitability, liquidity, efficiency, capital adequacy, asset quality), and management efficiency. In this work, we will review some main part of credit rating assessment.

This review paper aims to present and discuss the methodology of the largest world rating agencies. Given that rating agencies evaluate banks' risks and ratings, it is crucial to understand how this process is conducted, mainly because it affects the competitive position of banks.

\section{A methodological review of rating assessment}

The three largest rating agencies grouped banks (as well as other companies or countries) by the international rating scale, as listed in Table. Ratings from triple A to triple B refers to investment grades and ratings below triple B to RD from Fitch, Caa - from Moody's, and CC - from S \& P are speculative grades. Failure or total default grades are D and WD from Fitch; C, WR, and NULL - from Moody's; and NR, SD, NULL, and D - from S \& P. Investment grades refer to less risky banks (companies, countries, and securities) with a lower probability of default. 
Rating scale of major credit rating agencies

\begin{tabular}{|c|c|c|c|c|}
\hline & $\begin{array}{l}\text { Moody's } \\
\text { Long-Term } \\
\text { Issuer }\end{array}$ & $\begin{array}{l}\text { S \& P's } \\
\text { Long-Term } \\
\text { Issuer }\end{array}$ & $\begin{array}{l}\text { Fitch } \\
\text { Long-Term } \\
\text { Issuer }\end{array}$ & Grades explanations \\
\hline & & Rating & & \\
\hline & Aaa & AAA & AAA & $\begin{array}{l}\text { Highest credit quality (smallest degree of default) - } \\
\text { only for banks with the strongest and extremely stable } \\
\text { fundamental features }\end{array}$ \\
\hline 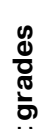 & $\begin{array}{l}\text { Aa1 } \\
\text { Aa2 } \\
\text { Aa3 }\end{array}$ & $\begin{array}{l}\text { AA+ } \\
\text { AA } \\
\text { AA- }\end{array}$ & $\begin{array}{l}\text { AA+ } \\
\text { AA } \\
\text { AA- }\end{array}$ & $\begin{array}{l}\text { High banks' credit quality (long term risk is some- } \\
\text { what higher compared to the previous rate): + highest, } \\
\text { - lowest in this group }\end{array}$ \\
\hline 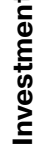 & $\begin{array}{l}\text { A1 } \\
\text { A2 } \\
\text { A3 }\end{array}$ & $\begin{array}{l}A^{+} \\
A \\
A-\end{array}$ & $\begin{array}{l}A^{+} \\
A \\
A-\end{array}$ & $\begin{array}{l}\text { Banks' upper-medium grade with the prospect of wea- } \\
\text { kening in the future: + highest, - lowest in this group. } \\
\text { Such banks could be more vulnerable to opposing busi- } \\
\text { ness or macro conditions than previous higher ratings }\end{array}$ \\
\hline & $\begin{array}{l}\text { Baa1 } \\
\text { Baa2 } \\
\text { Baa3 }\end{array}$ & $\begin{array}{l}\text { BBB+ } \\
\text { BBB } \\
\text { BBB- }\end{array}$ & $\begin{array}{l}\text { BBB+ } \\
\text { BBB } \\
\text { BBB- }\end{array}$ & $\begin{array}{l}\text { Banks' medium grade rating with the shortages of out- } \\
\text { standing investment features and with the low risk of } \\
\text { extraordinary support to avoid default: + highest, - lo- } \\
\text { west in this group }\end{array}$ \\
\hline & $\begin{array}{l}\mathrm{Ba} 1 \\
\mathrm{Ba} 2 \\
\mathrm{Ba} 3\end{array}$ & $\begin{array}{c}\mathrm{BB}+ \\
\mathrm{BB} \\
\mathrm{BB}-\end{array}$ & $\begin{array}{c}\mathrm{BB}+ \\
\mathrm{BB} \\
\mathrm{BB}-\end{array}$ & $\begin{array}{l}\text { Speculative bank's grade of rating with some proba- } \\
\text { bility of default (high vulnerability to opposing business } \\
\text { or macro conditions): + highest, - lowest in this group }\end{array}$ \\
\hline 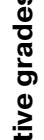 & $\begin{array}{l}\text { B1 } \\
\text { B2 } \\
\text { B3 }\end{array}$ & $\begin{array}{c}\mathrm{B}+ \\
\mathrm{B} \\
\mathrm{B}-\end{array}$ & $\begin{array}{c}\mathrm{B}+ \\
\mathrm{B} \\
\mathrm{B}-\end{array}$ & $\begin{array}{l}\text { Very speculative grade of rating with much more proba- } \\
\text { bility of material default: + highest, - lowest in this group }\end{array}$ \\
\hline$\frac{\pi}{\vec{\pi}}$ & Caa1 & $\mathrm{CCC}+$ & $\mathrm{CCC}$ & $\begin{array}{l}\text { The grade for poor standing with a good probability of } \\
\text { banks' default }\end{array}$ \\
\hline के & $\begin{array}{l}\text { Caa2 } \\
\text { Caa3 }\end{array}$ & $\begin{array}{l}\mathrm{CCC} \\
\mathrm{CCC}-\end{array}$ & $\begin{array}{l}\mathrm{CC} \\
\mathrm{C}\end{array}$ & $\begin{array}{l}\text { Highest speculative grade of rating with shortcomings } \\
\text { and very probable failure }\end{array}$ \\
\hline & Caa & $\mathrm{CC}$ & $\mathrm{RD}$ & $\begin{array}{l}\text { Lowest quality grades with minimal chances of invest- } \\
\text { ment standing }\end{array}$ \\
\hline 产 & $\begin{array}{c}\text { C } \\
\text { WR } \\
\text { NULL }\end{array}$ & $\begin{array}{c}\text { NR } \\
\text { SD } \\
\text { NULL } \\
\text { D }\end{array}$ & $\begin{array}{c}\mathrm{D} \\
\mathrm{WD}\end{array}$ & Failure grades \\
\hline
\end{tabular}
thors).

Source: Fitch Ratings, Moody's Investor Services and Standard and Poor's websites (modified by au-

Speculative grades refer to banks that they already downgrade in their rate and with a higher probability of default. However, such grades mostly offer high yields (junk bonds) with some higher risk, and because of these, they are in the speculative grades group. Failure or total default grades refer to banks (and other institutions) that are no longer able to repay their liabilities. The ratings in Table result from the analysis of numerous factors and their indicators. For more detailed explanations, we will discuss the methodology of Fitch Ratings. Although each of these rating agencies uses its methodology, they are substantially similar (Santos, 2012).

As the basis of analysis and assessment of ratings, Fitch observes several pillars: long-term default risk, short-term default risk, viability (company performance and organization), support, and derivative counterparty rating (see Figure). Fitch uses quantitative and qualitative assessments of various indicators, which can 
simply be expressed as economic and political factors (Verster et al., 2019). According to the same authors (2019) and Fitch (2014), these rates are the product of opinions, but not facts, and it cannot be express as accurate or inaccurate.

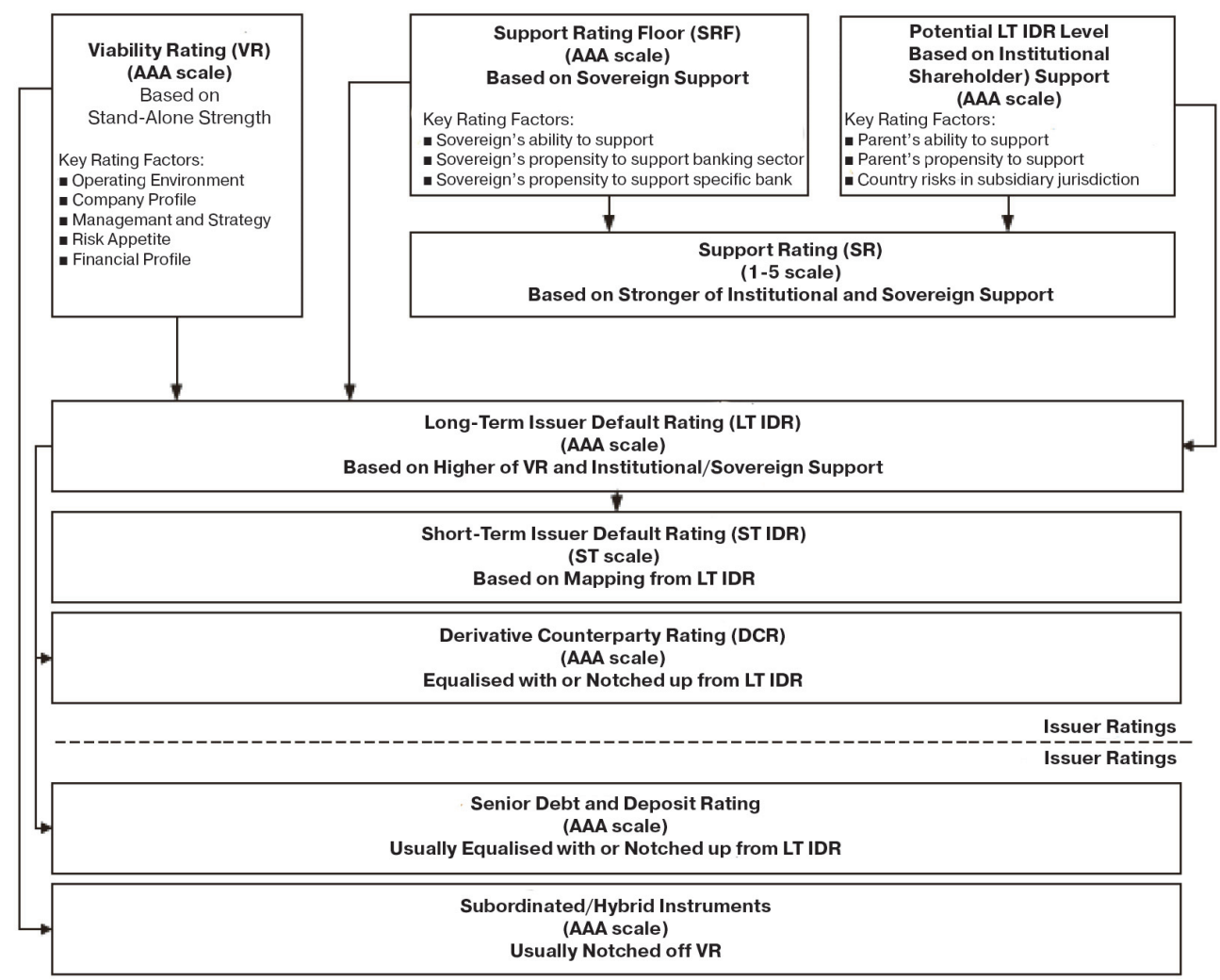

Figure. Fitch bank rating framework

Source: retrieved from Fitch.

The groups of these factors are analyzed by several indicators and ratios (Fitch, 2019). For the viability rating, they are group as operating environment, company profile, management and strategy, risk appetite, and financial profile. As support factors: sovereign ability to support system (size of banking system relative to economy, size of potential problem, structure of banking system, liability structure of banking system, sovereign financial flexibility), sovereign propensity to support system (resolution legislation with senior debt bail-in, track record of banking sector support, government statements of support), sovereign propensity to support bank (systemic importance, liability structure of bank, ownership, specifics of bank failure) and policy banks (policy role, funding guarantees, and legal status, government ownership). Many authors (Acharya et al., 2014; Brunnermeier et al., 2016; Gibson et al., 2016) spots that sovereign rating considerably affects bank performances. Securities issued from banks in the sovereign region were positively correlated with sovereign circumstances.

Bank's profitability ratios are one of the most important. Fitch analyze operating profit/RWA, NII/average earning assets, noninterest expense/gross revenue, 
net income/average equity, asset quality, impaired loans ratio, growth in gross loans, loan loss allowances/impaired loans, loan impairment charges/average gross loans, capitalization, Fitch core capital ratio, TCE ratio, CET 1 ratio, Basel leverage ratio, net impaired loans/FCC, funding \& liquidity, loans/customer deposits, LCR, customer deposits/funding. According to many literacies, risk appetite, economic and operational conditions, and financial ratios explain a large percentage (between 62-95\%) of risk model change (Chodnicka-Jaworska, 2019). This argument is supported by states that the qualitative measures are most imported in credit risk assessment (Karminsky, Khromova, 2016; Cole, White, 2012).

General, there is a higher consent of the authors about the assessment indicators of banks' credit risk. Except for financial ratios, we can mention capital adequacy, earnings, and short-term interest (Chodnicka-Jaworska, 2019; Shen et al., 2012; Pagratis, Stringa, 2007). Some studies have shown that bank size is one of the most critical factors (Chodnicka-Jaworska, 2019; Hassan, Barrell, 2013; Pagratis, Stringa, 2007). External factors can strongly influence the default risk of banks. For example, World Economic Outlook published from International Monetary Fund (IMF) announced the possibility of a crisis reducing global Growth compared to 2018 (from 3,7 to 3,5\%) (Boumparis et al., 2019), which can jeopardize financial conditions in international financial markets. For banks in the international market, this may mean a downgrade in rating. For example, increasing sovereign debts and borrowing costs in international markets will influence the lending supply of banks from sovereign countries and their investment decision (Drago, Gallo, 2017; Chen et al., 2016). Of course, the central role is again playing rating agencies calculating all these factors and assessing banks' position after changing market situation.

However, many authors believe that there are deficiencies in the assessment of banks' ratings from credit rating agencies. According to Chodnicka-Jaworska (2019), credit rating agencies react slowly to financial markets circumstances. Moreover, because of these claims, regulatory bodies are willing to decrease the role of credit rating agencies. In our opinion, this sounds reasonable due to the prolonged reaction of credit rating agencies nearly before the world crisis and their wrong evaluating of companies (banks) and instrument ratings. Even more, some authors argued that credit rating agencies default in prediction of corporates defaults in 2008 (Baghai et al., 2014; Ryan, 2012) or accelerated sovereign debt crisis in European Union in 2009-2010 or they question subjectivity in their assessment methods (Boumparis et al., 2017, 2019; De Moor et al., 2018). However, there is another problem with this issue. Banks usually give themselves a higher credit rating than they deserve and maybe could be questioned the reality of their ratings. A similar claim has Chodnicka-Jaworska (2019). How to trust them to be objective if they are assessing themselves? Even more, credit rating is also assessing in the national framework of countries, with similar methodologies: Moody's (2016) indicate as National Scale Ratings (NSR), Fitch as National Ratings (Fitch, 2014) and S \& P as National Scale Credit Ratings (S \& P, 2016). 


\section{Conclusion}

The main goal of this article was to review the principal methodologies of banks' credit rating assessment. We discussed the methodologies of Fitch as also reviewed literacy focused on different methodologies in credit rating assessment. Due to the reason that the competitive advantages of banks depend on their rating, many authors claim that banks are giving higher rates in their self-assessments. Because of this, the literature suggests that rating agencies' assessments are more appropriate. Even national ratings support this idea (Moody's, 2016; Fitch, 2014; $\mathrm{S} \& \mathrm{P}, 2016)$. However, there is no too much literacy about the factors defining credit ratings of more significant users, like commercial banks.

In many cases, it turned out that the qualitative methodology (CAMEL) with only specific indicators explained the majority of bank's rating (Chodnicka-Jaworska, 2019; Shen et al., 2012; Pagratis, Stringa, 2007; Karminsky, Khromova, 2016; Cole, White, 2012). On the other side, banks located in the sovereign regions are strongly influenced by support factors and sovereign variability (Drago, Gallo, 2017; Chen et al., 2016). Moreover, some authors point out the bank's size as essential indicators; however, not too much literacy analyzed this claim (Hassan, Barrell, 2013; Pagratis, Stringa, 2007), which do not diminish the significance of this argument.

Also, some authors strongly believe that major credit rating agencies failed in their assessments before crisis and even more, they deepened and generated the crisis (Baghai et al., 2014; Ryan, 2012; Boumparis et al., 2017; De Moor et al., 2018; Boumparis et al., 2019). All this raises the question of how much to trust rating agencies if, in the most critical moments, they have proven to be slow or have given incorrect assessments. Second, if we rely on our bank estimates, we will have overestimated assessment rates. The certain is that numerous literature will address this issue and search for the best assessment methodology.

\section{References}

Acharya, V., Drechsler, I., \& Schnabl, P. (2014). A pyrrhic victory? Bank bailouts and sovereign credit risk. The Journal of Finance, 69(6), 2689-2739.

Boumparis, P., Milas, C., \& Panagiotidis, T. (2017). Economic policy uncertainty and sovereign credit rating decisions: Panel quantile evidence for the Eurozone. Journal of International Money and Finance, 79, 39-71.

Boumparis, P., Milas, C., \& Panagiotidis, T. (2019). Non-Performing Loans and Sovereign Credit Ratings. Working Paper 19-13. Retrieved from rcea.org/RePEc/pdf/wp19-13.pdf

Brunnermeier, M.K., Garicano, L., Lane, P.R., Pagano, M., Reis, R., Santos, T., \& Vayanos, D. (2016). The sovereign-bank diabolic loop and ESBies. American Economic Review, 106(5), 508-512.

Chen, S.S., Chen, H.Y., Chang, C.C., \& Yang, S.L. (2016). The relation between sovereign credit rating revisions and economic Growth. Journal of Banking and Finance, 64, 90-100.

Chodnicka-Jaworska, P. (2019, February). Banks and Shareholders Credit Ratings - Evidence from the European Market. UW Faculty of Management Working Paper Series, (6). Warsaw, Poland. 
Cole, R.A, \& White, L.J. (2012). Déjà Vu all over again: The causes of U.S. commercial bank failures this time around. Journal of Financial Services Research, 42, 5-29.

De Moor, L., Luitel, P., Sercu, P., \& Vanpée, R. (2018). Subjectivity in sovereign credit ratings. Journal of Banking and Finance, 88, 366-392.

Drago, D., \& Gallo, R. (2017). The impact of sovereign rating changes on the activity of European banks. Journal of Banking and Finance, 85, 99-112.

Fitch. (2019). Definitions of ratings and other forms of opinion. Fitch Ratings, New York.

Gibson, H.D., Hall, S.G., \& Tavlas, G.S. (2016). How the euro-area sovereign-debt crisis led to a collapse in bank equity prices. Journal of Financial Stability, 26, 266-275.

Grunert J., Norden L., \& Weber M. (2005). The role of non-financial factors in internal credit ratings. Journal of Banking and Finance, 29(2), 509-531.

Hassan, O.A.G., \& Barrell, R. (2013). Accounting for the determinants of banks' credit ratings. Brunel University of London Economics and Finance Working Paper Series, 13-02.

Karminsky, A.M., \& Khromova, E. (2016). Extended Modeling of Banks' Credit Ratings. Procedia Computer Science, 91, 201-210.

Moody's. (2016). Rating symbols and definitions. Moody's Investors Services, London.

Pagratis S., \& Stringa, M. (2007). Modelling bank credit ratings: A structural approach to Moody's credit risk assessment. Working paper.

Ryan, J. (2012). The negative impact of credit rating agencies and proposal for better regulation, SWP, Berlin. Working paper FG 1, 2012/Nr.01.

S \& P. (2016). $S \&$ P global ratings definitions. McGraw-Hill Companies, New York.

Santos, K. (2012). Corporate credit ratings: A quick guide, the association of corporate treasurers handbook. Retrieved 19 July 2016 from https://www.treasurers.org/ACTmedia/ ITCCMFcorpcreditguide.pdf

Shen, C., Huang, Y., \& Hasan, I. (2012). Asymmetric benchmarking in bank credit rating. Journal of International Financial Markets, Institutions \& Money, 22, 171- 193.

Verster, T., De Jongh, R., Greenberg, S., Fourie, E., \& De Wet, D. (2019). A motivation for banks in emerging economies to adapt agency ratings when assessing corporate credit. South African Journal of Economic and Management Sciences, 22(1), a2818. https:// doi.org/10.4102/sajems.v22i1.2818

\section{Article history:}

Received: 20 December 2019

Revised: 12 January 2020

Accepted: 25 January 2020

\section{For citation:}

Grigorieva, E.M., \& Vukovic, D. (2020). Assessing methodology of banks' ratings and their competitive positions: Overview of main rating agencies. RUDN Journal of Economics, 28(1), 23-30. http://dx.doi.org/10.22363/2313-2329-2020-28-1-23-30

\section{Bio notes:}

Elena M. Grigorieva, Cand. Sc. (Econ.), Associate Professor, Peoples' Friendship University of Russia (RUDN University).E-mail: aroooveo@yandex.ru

Darko Vukovic, $\mathrm{PhD}$, Associate Professor, Peoples' Friendship University of Russia (RUDN University).E-mail: vdarko@hotmail.rs 
Научная статья

\title{
Оценка рейтингов банков и их конкурентных позиций: обзор методологий рейтинговых агентств
}

\author{
Е.М. Григорьева, Д. Вукович
}

Российский университет дружбы народов

Российская Федерация, 117198, Москва, ул. Миклухо-Маклая, 6

В статье анализируются подходы к оценке кредитного рейтинга крупных рейтинговых агентств. Целью исследования является обзор методологий оценки кредитного рейтинга банков. Изучаемые методологии оценки были получены из Fitch Ratings. Pacсматривается международная буквенная категория с точки зрения факторов и показателей адекватности в рейтинговых оценках. В результате исследования было выявлено, что соотношения финансовых показателей являются наиболее важными для оценки кредитного рейтинга. Авторы пришли к выводу, что подходы к рэнкингу еще недостаточно изучены и в будущем число исследований с различными методологическими предложениями и улучшениями будет увеличиваться.

Ключевые слова: кредитный рейтинг, банки, рейтинговые агентства, методология, оценка, Fitch

\section{История статьи:}

Дата поступления в редакцию: 20 декабря 2020

Дата проверки: 12 января 2020

Дата принятия к печати: 25 января 2020

\section{Для цитирования:}

Grigorieva E.M., Vukovic D. Assessing methodology of banks' ratings and their competitive positions: overview of main rating agencies (Оценка рейтингов банков и их конкурентных позиций: обзор методологий рейтинговых агентств) // Вестник Российского университета дружбы народов. Серия: Экономика. 2020. Т. 28. № 1. С. 23-30. http://dx.doi.org/10.22363/2313-2329-2020-28-1-23-30

\section{Сведения об авторах:}

Григорьева Елена Михайловна, кандидат экономических наук, доцент, Российский университет дружбы народов. E-mail: aroooveo@yandex.ru

Вукович Дарко, кандидат экономических наук, доцент, Российский университет дружбы народов. E-mail: vdarko@hotmail.rs 